\title{
Language, culture and ideology in discursive practices
}

\author{
Magdaléna Bilá ${ }^{1}$ and Svetlana V. Ivanova ${ }^{2}$ \\ ${ }^{1}$ University of Prešov \\ Prešov, Slovakia \\ ${ }^{2}$ Pushkin Leningrad State University \\ Saint Petersburg, Russia
}

\begin{abstract}
Discursive practices are looked upon as the core notion of discourse theory and the main instrument linguists can operate with studying language in connection with society and a human being. In this introductory article we will look into how language, culture and ideology are intertwined in diverse discursive practices and how these practices are shaped by people representing various cultures, ideologies and social entities. As part of linguistic discourse theory, we will briefly outline the major objectives and tenets of discourse theory or discourse analysis and track down the reasons why discourse theory turned into a dominant linguistic paradigm in the new millennium. Besides, some light will be thrown on the advancements and debatable questions arising within discourse theory as reflected in its methodology. Then we will give a brief synopsis of each individual paper and highlight theoretical and methodological contributions and innovations proposed by our authors. The results of the discussion as well as a brief outlook on future research will be summed up at the end of the introductory article.
\end{abstract}

Keywords: discourse analysis, discursive practices, culture, ideology, identity

For citation:

Bilá, Magdaléna and Svetlana V. Ivanova. 2020. Language, culture and ideology in discursive practices. Russian Journal of Linguistics 24 (2). 219-252. DOI: 10.22363/2687-0088-202024-2-219-252

Вступительная статья

\section{Язык, культура и идеология в дискурсивных практиках}

\author{
М. Била ${ }^{1}$, С.В. Иванова ${ }^{2}$ \\ ${ }^{1}$ Прешовский университет в Прешове \\ Прешов, Словакия \\ 2 Ленинградский государственный университет имени А.С. Пушкина \\ Санкт-Петербург, Россия
}

\begin{abstract}
Аннотация
Дискурсивные практики рассматриваются в качестве основополагающего понятия теории дискурса и основного инструмента, при помощи которого лингвисты могут изучать язык в связи с обществом и человеком. Данная вводная статья, как и весь выпуск, посвящены
\end{abstract}


вопросу о том, как язык, культура и идеология переплетаются в различных дискурсивных практиках и как эти практики формируются людьми, представляющими разные культуры, идеологии и социальные образования. Рассматривая дискурсивные практики как часть лингвистической теории дискурса (дискурс-анализа), мы кратко опишем основные цели и принципы теории дискурса и выделим причины, по которым это направление превратилось в доминирующую лингвистическую парадигму нового тысячелетия. Кроме того, мы остановимся на развитии теории дискурса и тех дискуссионных вопросах, которые возникают в ее рамках. Проблемные зоны теории дискурса касаются расширения предметной области дискурс-анализа, избираемых дискурс-аналитиками объектов исследования, стыковых дисциплин, граничащих с теорией дискурса, и методологии анализа. В завершение мы дадим краткий обзор каждой статьи номера и отметим теоретический и методологический вклад, а также новизну каждой публикации. Результаты и перспективы будущих исследований очерчены в заключительной части вводной статьи.

Ключевые слова: дискурс анализ, дискурсивные практики, культура, идеология, идентичность

\section{Для цитирования:}

Bilá, Magdaléna and Svetlana V. Ivanova. 2020. Language, culture and ideology in discursive practices. Russian Journal of Linguistics 24 (2). 219-252. DOI: 10.22363/2687-0088-202024-2-219-252

To imagine a world without discourse is to imagine a world without language and therefore to imagine the unimaginable.

(He 2003: 428)

\section{Introduction}

The focus of this issue is discourse and the way it is molded by homo loquens in different spheres of human activities. The authors of the issue throw light on how language, culture and ideology are intertwined in diverse discursive practices and how these practices are shaped by people representing various cultures, ideologies and social entities. This is not the first issue of our journal that is devoted to discourse and discursive practices (see issues 2006, 4; 2017, 1; 2018, 1; 2019, 4). But there is a certain reason why we continue this quest. Discourse is a cover term including all forms of language use, which makes discourse the only known real linguistic object (Kibrik 2009: 1). Notwithstanding the fact that many a book (Blommaert 2005, Fairclough 1992, 2003, Gee 2007, Johnstone 2018, Karasik 2002, Schiffrin 1995, van Dijk 2006, 2009, 2011 and many more) is devoted to discourse, it has not lost its attraction to linguists due to several important reasons. It enables researchers to focus their effort on a human engaged in any kind of activity or interaction. In discourse studies speakers acquired diverse characteristics as biological, social, cultural, ethnic, professional beings and, as a consequence, the understanding of the significance of all types of environment in speech production led to the awareness of its formative role in the use of language at large. Discourse made it possible to 'put language, action, interaction, values, beliefs, symbols, objects, tools, and places together in such a way that others recognize you as a particular type of who (identity) engaged in a particular type of what (activity), here 
and now' (Gee 1999: 27). Thus, le langage, the ethereal and insufficiently substantiated notion which was put forward by Saussure, became more tangible.

\section{Major tenets and objectives of discourse theory}

For several decades, linguists had been concentrating their effort on the structure of language (Saussure's la langue) until it became evident that linguistics could not stay within those rigorous borders (Yule 1999: 139-140). First the mesmerizing effect of language in use made scholars shift their attention to speech (Saussure's parole). Then the combination of diverse factors, including the emergence of the term discourse in Harris's work in 1952 (Harris 1952), Chomsky's revolution in linguistics with his emphasis on competence vs. performance (Chomsky 1965), the study of discourse by French scholars (e.g. Foucault 1981, 1994), to name just a few - all led to an understanding of discourse as some kind of fabric produced by homo loquens (Hagege 1985) with two major interwoven threads, those of language and reality (Foucault 1994).

A comprehensive study of discourse began with the scholars' search for the universal definition of this phenomenon which is characterized by a complex and multidimensional nature. In this respect eight approaches to the definition of discourse outlined by Sériot (Seriot 1999) are still quite representative and expository, starting with the interpretation of discourse as an equivalent to Saussure's parole and going to the conditions under which a certain text is generated, with all the restrictions set by the former (ibid.: 26-27). Eventually, discourse got its interpretation as a human activity aimed at creating some meaningful thought in a verbalized form. This approach brought to the fore the circumstances discourse is created in and the individual it is connected with. As a consequence, linguists turned to the study of an interplay of different factors that operate in discourse, shaping and molding it in the speaker's mode. In the long run, a human being became the centerpiece of linguistic studies with discourse as the major manifestation of human activities and their multifarious relations.

In the network of the relationships between humans, language and culture, humans are defined as biological, social and cultural beings with all these aspects closely bound together and constituting a single integral, inseparable package. Biological characteristics of humans determined by the evolution and genetic data are gradually transformed in the accommodation-assimilation processes and modified through social interaction and socialization, thus converting humans into social and cultural beings (Dolník 2015). The awareness that people as biological, social and cultural beings use language to mediate all their activities encouraged linguists to study language in various contexts, which they believed would help to untie that tight knot. The statement made by Nunan (1993) that "discourse brings together language, the individual producing the language, and the context within which the language is used" (1999: 6-7), is shared by all those who these days deal with discourse in linguistics. It is generally agreed that the term "discourse usually refers to the interpretation of the communicative event in context" (Dijk 
2009: 1). This makes context an essential concept in discourse analysis (Nefedov \& Chernyavskaya 2020). Context as "a set of relevant properties of the communicative situations of verbal interaction" (Dijk 2009: vii) refers to the situation giving rise to discourse, and within which discourse is embedded. In this light discourse "refers to the set of norms, preferences, and expectations relating language to context, which language users draw on and modify in producing and making sense out of language in context" (Saville-Troike 1994: 358).

Traditionally, linguists single out two different types of context. The first of these is linguistic or verbal context (also referred to as micro-context or co-text), i.e. the language that surrounds or accompanies a piece of discourse under analysis. The second is non-linguistic or non-verbal or experiential context within which discourse takes place (also referred to as macro-context). It is shaped by a number of factors including the type of communicative event (e.g. a joke, a story, a lecture, etc.); the topic; the purpose of the event; the setting; the participants and the relationships between them; and the background knowledge underlying the communicative event (Nunan 1993: 7-8). As Kecskes (2014) points out, in linguistics "contexts usually refer to any factor - linguistic, epistemic, physical, social - that affects the actual interpretation of signs and expressions" (Kecskes 2014: 35). He suggests distinguishing between prior context which is in our mind (pragmatic context) and actual situational context, emphasizing that "meaning is the result of the interplay of prior experience and current, actual situational experience, which are both socio-cultural in nature" (ibid: 129).

The use of language in a variety of contexts (situational, geographic, historical, structural, institutional), a discourse, is also understood as a three-dimensional concept (as text, discursive practice and social practice) (Fairclough 1992). As a social practice discourse is an entity embedded in social and historical context. What is more, it subsequently participates in the social construction of reality and is responsible for socially modeling a community and creating social identities, enhancing knowledge, shaping social relations and generating complex discursive practices and discourse conventions (Resta 1998, van Dijk 2006).

Another important finding that came with discourse studies was the understanding of cognition and discourse closely tied together. It became clear that "discourse intervenes between thought and reality" (Williams 1999: 23). Within the cognitive framework of discourse theory, it is argued that humans mentally capture their environment and integrate it into concepts, systems and relationships, i.e. conceptualize it. Conceptualization can be understood as a mental grasp, segmentation, specification and categorization of data pertaining to the material and abstract world and subsequently processing it in thought and language. In individual lingua-cultural communities, these processes take place within specific interpretation frameworks governed by the internalized cultural patterns and conventions. Thus, in different cultures, people schematize their experience and knowledge of the world differently. As a result, languages differ on the basis of "accumulated declarative knowledge $<\ldots>$ and culturally conditioned schemes" 
(Kecskes \& Papp 2000), in other words, languages are socially and culturally embedded entities.

Discourse analysis became a dominant paradigm ranging over all the human sciences, an air du temps, in Sériot's terms (Sériot 2012: 18). Researchers belonging to different linguistic schools tried to describe formal and functional features of the latter (Schiffrin 1995). Later on, a third dimension of the discourse was added, that was the description of topoi underlying its certain types (Dobrosklonskaya 2014: 182). Thus, discourse made an overwhelming object of analysis uniting the humanities in their search for semiotically expressed (Fairclough 2004: 225-226) social psychological, sociological, and anthropological patterns (Dijk 2009) of reproducing social identity.

\section{Modern challenges for discourse theory}

Modern linguistic discourse studies develop in several directions predetermined by a complex nature of the phenomenon under scrutiny. Scholars have been trying to achieve more precision in defining the object and the subject matter of discourse theory. Besides, another challenge is elaborating reliable methods which could be used in linguistics to explore the sphere of analysis, to describe types of discourse and discursive practices engaged in order to maintain existing or emerging social relations.

In compliance with the socio-philosophical understanding of discourse, initially, linguists turned to those spheres of communication where power and domination in society was consistently reproduced (van Dijk 2011: xvii). These were political (van Dijk 2006, Fairclough 1989), news (van Dijk 1988, Fowler 1991), mass media (van Dijk 1985), and legal (Goodrich 1987) discourses. Very soon this list grew and linguists' interest turned to such spheres as advertising (Cook 1992), marketing (Skålén et al. 2008), medical (e.g. Good, Del Vecchio Good 1981, Locher 2017), classroom (e.g. Christie 2002), academic (e.g. Hyland 2009) discourses. All these types of discourse retain their scholarly significance, with the scope of research only widening when it comes to political (e.g. Beard 2000, Chilton 2004, Ponton 2016, Sheigal 2004, Solopova \& Chudinov 2018,), mass media (e.g. Bell \& Garett 1992, Dobrosklonskaya 2014, Dubrovskaya \& Kozhemyakin 2016; Larina et al 2019, Macdonald 2003, Matheson 2005, Ozyumenko 2017, Talbot 2007), news (e.g. Bednarek 2006, Montgomery 2007), religious (e.g. Bobyreva 2007, Naydenova 2018, Wierzbicka 2018) and judicial / legal (e.g. Gotti \& Williams. 2003, Dubrovskaya 2017) discourses. Moreover, linguists started reconnoitering new spheres, including Internet discourse (Crystal 2010), entertainment / leisure and consumer discourse (e.g. Fullagar 2002, Molodychenko 2016), lifestyle discourse (e.g. Ivanova 2019, Molodychenko 2020), tourist discourse (e.g. Jaworski, Thurlow 2010), gender discourse (e.g. Mills 2003), sports discourse (e.g. Koshkarova 2019), gastronomic discourse (e.g. Olyanich 2003), urban discourse (e.g. Leontovich 2019), green discourse (e.g. Alexander \& 
Stibbe 2014) and many others. This all proves the statement made by Issers that the list of types of discourse can never be complete (Issers 2011: 227).

The framework of discourse theory provided an important perspective for many objects of linguistic description. One of these new fields of discourse theory expansion became the study of emotions (e.g. Alba-Juez \& Larina 2018, Mackenzie \& Alba-Juez 2019, Shahovsky 2015, 2018; among many others). Linguists saw a link between emotions and certain contexts which generate "a multimodal discourse process, which permeates all linguistic levels but also manifests itself in non-verbal ways, presenting different stages and forms (influenced by variables such as pragmatic expectations or common-ground knowledge) according as the discursive situation and interaction changes and evolves" (Mackenzie \& Laura Alba-Juez 2019: 18). The discourse approach to emotion made it possible to show this phenomenon as a dynamic, discourse-pragmatic entity. This "emotional turn" inevitably caused some changes in the subject matter of discourse analysis - it went far beyond current knowledge of how a human being constructs their social identity in different types of interaction (e.g. Langlotz \& Locher 2017, Larina et al 2017).

A salient field of exploration discourse analysis borders on is communication. What do spheres, types and forms of communication, on the one hand, and types of discourse, on the other - have in common and what are their distinctive features so that linguists could tell them apart? Interestingly, discourse analysis gave rise to a term that unites these two notions, i.e. a discursive practice. The scope of interpretation of this Foucauldian term ranges from "the production, distribution and consumption of texts" (Fairclough 1992: 5, 73, 2010) to "the practices (or operations) of discourses, meaning knowledge formations" without any reference to linguistic practices or language use (Bacchi \& Bonham 2014: 173). In spite of this contradiction between scholars, the majority of linguists follow the "linguistic turn" according to which discursive practices are a linguistic reflection of social practices defined as "a relatively stabilised form of social activity" (Fairclough 2001: 231). Therefore, scholars delve into the analysis of discursive practices as mechanisms of discursive construction of various types of relations, starting with power distribution and going into diverse types of communication. In this respect it is only logical that the study of discourse turned out to be closely connected with the study of communication with its various communication strategies.

Another case of the extension of the discourse analysis field is incorporating the study of im/politeness strategies converting them into discursive practices. The discursive approach to politeness (Eelen 2001, Mills 2003, Watts 2003) gave a new impetus to the development of the theory of politeness, significantly widening its scope. The most important contributions of the discursive turn were "to remind us of the evaluative and situated nature of concepts such as impoliteness or politeness, the importance that emotions play in assessments and to argue for the link of identity construction with these processes of judging" (Locher \& Larina 2019: 875).The study of impoliteness also emerges from the discursive focus on language 
(e.g. Bousfield \& Locher 2008, Culpeper 2011, Garcés-Conejos Blitvich \& Sifianou 2019). As Culpepper (2011) rightly states, impoliteness is an important aspect of social life and it plays a central role in many discourses which are rarely described in detail (Culpeper 2011: xiii). Both politeness and impoliteness involve the study of particular communicative behaviour in social interaction with the focus on context (e.g. Bousfield 2008, Fernández-Amaya 2019).

Within linguistics, discourse analysis posited another set of acute questions since it was necessary to fit in the new object of analysis and find its own niche in relation to traditional spheres of linguistic analysis. Discourse understood as a Gestalt-cognitive entity having a certain invariant model and characterized by prototypical properties, was confronted with the long-existing and well-established notions recognized by the scholarly community of linguists and philologists, in this case that of genre as 'as a set of expectations that a reader acquires from his/her reading', 'a self-contained system with its own codes and conventions' (Corbett 2009: 287). There was an opinion that linguistics should shun the notion of genre and replace it by the term discourse. It took time to work out a balanced approach and make the terminology compatible. Now genre studies within discourse analysis (e.g. Dementyev 2016, Fuentes Rodríguez \& Álvarez-Benito 2016, GarcésConejos Blitvich, 2010, Ivanova 2017) is a topical issue (Dijk 2009: 8). It should be understood that this seems to be not only a problem of terminology but also of what we, linguists, really work with when it comes to studying units larger than sentence, the embodiment of language in use.

This broadening of the subject matter and diversification of the object of analysis brought about another challenge for linguists involved in discourse analysis, i.e. the choice of methods and the veritability of results they yield. Needless to say, the extent and the severity of the methodological problem are predetermined by the multidimensional nature of discourse and its status in the humanities. It is common knowledge that linguistic discourse analysis is an outcropping of discourse analysis in the humanities which emerged in the 1960s. Due to French structuralism discourse came into research as an object of sociology. Thus, it was first studied in social sciences with the help of sociological methods. It took linguistic discourse analysis some time to elaborate its own approach to research. The seminal publications (Jørgensen \& Phillips 2002, Titscher et al. 2000) made quite a step in this respect expounding a whole array of methods which could be employed by discourse analysts.

Another difficulty with methodology stems from the inter- or even transdisciplinary status of discourse analysis. The focus of discourse theory or discourse analysis on language, society and a human being requires research within overlapping boundaries of different research fields. It brings in interdisciplinary methods and interdisciplinary teams to work on the problems put to the fore. Interdiciplinarity has always been an integral tenet of discourse analysis, critical discourse analysis (CDA) or critical discourse studies (CDS). Unger (2016) finds this approach as the manifestation of linguistic scholars' natural need to cross "the 
sometimes staid and rigid disciplinary boundaries of linguistics" (Unger 2016: 2). This approach is taken at theoretical, methodological and research context levels in that discourse analysis or CDS draws on other fields of inquiry (such as sociology, psychology, cognitive science, philosophy, etc.), makes use of methodologies also applied in different fields (text linguistics, corpus linguistics, ethnography, etc.) and explores all kinds of phenomena which share an affinity with the use of language. As a proponent of interdisciplinarity, he claims that "looking sideways" may be beneficial for discourse analysts in making an effort to incorporate theories from different disciplines into their analysis in order to better grasp discursive practices in their social contexts (Unger 2016: 2). In his analysis of diverse CDS approaches, Unger (2016) observes that they are aligned to three dimensions, namely textual, social and cognitive/mental. These dimensions are interrelated and involved in each approach, though to varying degrees, thus laying varied emphasis on investigating and clarifying phenomena that are respectively textual, social or cognitive/mental.

All these problems have been actively discussed in the framework of discourse theory and scholarly fields adjacent to it. In the recent years, more often than before, scholarly publishing on the problems of discourse theory has significantly expanded in volume and the number of conferences on this topical issue has been only increasing. The idea of this issue was born at "Language in Modern Discursive Practices", within the Firsova Readings - IV, a traditional biannual conference that was held on October 22-23, 2019 at the RUDN University supported by the Institute of modern languages, intercultural communication and migrations. The international team of plenary speakers - Miriam A. Locher (University of Basel, Switzerland), Laura Alba-Juez (UNED, Madrid), Magdaléna Bilá and Ingrida Vaňková (University of Prešov, Slovakia), Dániel Z. Kádár (Hungarian Academy of Sciences \& Dalian University of Foreign Languages), Monika Kopytowska (Lodz University, Poland) - covered many of the problems addressed in this issue. The reports presented showed that discursive practices are being researched in different types of discourse and they could be analyzed from different perspectives: the way they are employed to express emotions, politeness and impoliteness, hate speech, etc.

\section{Issues covered in the collection}

This issue is coming out in hard times and we are thankful to everyone who, at this difficult time of corona virus pandemic, continues to work and share their thoughts and ideas, including those related to challenges that go beyond the field of linguistics. The issue opens with Anna Wierzbicka's address to all of us united in our fight against the pandemic which acquired the shape of a global social event, with seven essential messages. Using her Natural Semantic Metalanguage method, which allows thoughts to be accurately conveyed in all languages of the world (Goddard and Wierzbicka 20014, Wierzbicka 1996), Anna Wierzbicka has found simple, transparent words - words that can be understood and taken in instantaneously, by anyone. We can only hope that these words can help us cope 
with the hardships and difficulties of this period, find new prospects and stay positive.

All the works presented on the pages of the special issue focus on the analysis of discursive practices. Studying different angles of the language, culture and ideology interaction through the prism of discourse, the authors thereby expand and refine our knowledge about the processes of social life occurring at the micro and macro levels. The basis for research of this kind stems from the idea that discourse "involves focusing upon a social construction of meaning" (Williams 1999: 5).

Anna Wierzbicka's address is followed by her article "Addressing God in European languages: Different meanings, different cultural attitudes" in which she investigates how speakers of different European languages tend to relate to God. The aim the author sets complies with an understanding that as cultural beings, humans manifest themselves through standardized manners of accommodative behavior. In the course of socialization, humans develop a variety of (verbal) behavior patterns and various modes of interpreting the world, which results in the emergence of an array of lingua-cultural communities (Dolník 2015). The relationship between humans, language and culture has been the focus of research in humanities from the very beginning. This interest has been an ongoing feature of modern linguistics for quite a while and it reveals the way language is used to serve its purpose according to the aim of the user, the context of use and the internalized cultural patterns governing its mechanisms. Thus, each lingua-culture has their own characteristic ways of addressing God, encoded in certain words, phrases, grammatical forms, and formulae which both reflect and shape the speakers' habitual ways of thinking about God and relating to God. Often, they also reflect some other aspects of their cultural memory and historical experience. The results of the study show that each European language offers its users a range of options for addressing God. Some of these options are shared; others appear to be unique to the language. All are underpinned by broader historical phenomena. Still as the author maintains, the exact nature of all these links remains to be investigated.

During socialization, people develop different (verbal) patterns of behavior and different ways of interpreting the world, which leads to the emergence of many language communities (Dolník 2015). The next three articles of the current issue examine the relationship between ideology, identity and language in various discursive practices in different language communities. Ideologies represent social groups, define and are defined by their social practices.

Language is all around us, permeating our public and private lives, materialized in the form of speech sounds and displayed in texts taking the form of shop signs, public and private notices, posters, commercial slogans, etc. Martin Pütz explores the linguistic landscape of Cameroon sharing his reflections on language policy and ideology. He dwells on linguistic landscape as a relatively recent area of research, which he defines as the visual representation of languages in public space. Cameroon's linguistic landscape is composed of English, French, Pidgin English, Camfranglais and, to a minor degree, indigenous African 
languages. This paper shows that the field of linguistic landscapes can act as a reflection of linguistic hierarchies, ideologies and acts of resistance in multilingual and multicultural communities. Besides, in Cameroon the linguistic landscape almost exclusively focuses on the dominant status and role of one single language, i.e. French, and to a lesser extent English, whose speakers therefore feel marginalized and oppressed by the French-favouring government. The paper presents certain interest from the point of view of its methodology as the author analyses more than 600 linguistic tokens (digital photos) that he collected in various public places mainly in and around the Cameroonian capital of Yaoundé.

Stephany Moody and Zohreh Eslami turn to political discourse, codeswitching and ideology. The authors concentrate on mechanisms of manipulation, suggestion, and persuasion inherent in language. They study code-switching in political discourse, which is considered as one of the discursive practices employed by bi- and multilinguals. Through these practices, they utilize their entire linguistic repertoires to create meaning by way of switching between two or more available languages or dialects with respect to certain extralinguistic factors to gain support of their political followers. Code-switching captures the historical, political and social embeddedness of language practices and the manners in which these practices are intertwined with ideologies. Based on language ideologies framework, the paper seeks to determine how code-switching was used as political discourse by Senator Kaine, and how its use varied based on the context of each speech. The study illustrates how code-switching can be used to cultivate political favour, forge alliances, and demonstrate cultural similarities between white politicians and biand multilingual voters.

In their paper, Magdaléna Bilá, Alena Kačmárová and Ingrida Vaňková address the encounter of two lingua-cultures through the perspective of social deixis. It is a well-known fact that in most languages, mainly European ones, conveying social deixis operates on a sliding scale between two extremes: $\mathrm{T}$ and $\mathrm{V}$ forms. The paper reports on research on Slovak and English languages that respectively have and lack overt T/V markers. The uniqueness of English vs. Slovak cultural identity and/or discursive practice of the respective culture with regard to expressing social distance are examined in two steps. Firstly, the related concepts (a cultural identity, social distance, $\mathrm{T} / \mathrm{V}$ forms) are analyzed by means of the conceptualizing scheme (frame establishment, encoding/pre-understanding, contextualization/salience, and code configuration). Secondly, the questionnaires were designed based on the outcomes of the conceptualization process involving a set of principles. The outcomes of the investigation show that conceptualization of $\mathrm{T}$ vs $\mathrm{V}$ or informal vs. formal may stem from the conceptualization of social distance in terms of a set of principles, the conceptualization of the specific principle in terms of the relationship types, the conceptualization of the relationship type in terms of a specific culture and the conceptualization of a culture-specific relationship type through language means ( $\mathrm{T}$ or $\mathrm{V}$ ). 
Various discursive practices are discussed in a number of articles. Natalia Sokolova brings to the fore some methodological questions in her integrated approach investigation analyses of multimodal marketing discourse. The paper investigates the multimodal website marketing discourse relying on an approach which makes use of multimodal critical discourse analysis, pragmatics, and text linguistics. The integrated framework allows for consideration of the discoursegenerating intention of the locutionary source, the discourse function, verbal content categories and audio-visual techniques employed in the nonverbal discourse contributing to the global category of ideologeme made of key ideas and aimed at the locutionary target. It is of particular interest that the linguistic means in the three marketing discourses under analysis are different only when it comes to metaphorical expressions. The global ideologeme is made explicit by urging customers to optimize data and feel IT-powered performance benefits. It is conveyed through multiple antitheses, such as data challenges vs. one solution, previously vs. now, old vs. new and slowly vs. fast. The antitheses in the three marketing discourses are similar as are the typical manifestations of categories and audio-visual techniques which may encourage further research in terms of making the specific discourse of a company stand out to its customers.

Svetlana Ivanova and Gulnara Khakimova investigate celebrity gossip as a genre in English-language mass media discourse. The paper studies rumours as a specific communication phenomenon and the discursive practices by means of which it is realized across the Anglophone mass media discourse continuum. The integrative approach with various methods employed makes it possible to gain an insight into media rumours, namely celebrity gossip, manifested in on-line versions of the printed press and original web outlets. The study reveals restrictions imposed on this text type and the range of topics discussed, i.e. what makes this genre distinct from others. The structure of the celebrity gossip discourse is represented by texts in different journalistic forms: ranging from informative genres to feature type variations used by authors as means of constructing celebrity culture. The information of trivial content and questionable validity because of its unverified character is disguised as reports of high testimonial trustworthiness and epistemic value with the help of a variety of language and textual resources. The authors argue that within the mass media communication there exists a specific discourse which is hybrid by nature and non-evidential by verification.

Aleksey Romanov and Olga Novoselova unveil pragmatic effectiveness of threat statements in political communication. The aim of the article is to consider pre-election statements with the meaning of threat as verbal regulative actions and to propose a typology of such constructive menacives taking into account the targeted orientation of their consequent component. The theoretical framework of the study is made up by the theory of speech activity, speech act theory and psychosemantics. The study identified 18 targeted types of menacives from the point of view of their pragmatic and emotional potential for influencing voters which are characterized by different frequencies in pre-election programs. The 
authors conclude that politicians deliberately prefer to use threat statements with consequent effect on an unfocused audience trying to win the attention and votes. The analysis shows that four types of threat statements with different targeting of consequent component was a pragmatically effective tool in the context of the Russian pre-election campaign in 2018. The results of this study can be used to predict the pragmatic effect of politicians' threat statements on voters.

Sergey Pashkov in his work accentuates the importance of the holistic view of the world that is relevant for text studies. The purpose of the article is to analyze and classify the language means representing emotions which biblical characters attribute to God. On the basis of theological interpretation of the antinomy 'God's immutability-God's emotions' the author substantiates (1) the introduction of the term 'attribution of emotions' in the conceptual and terminological apparatus of emotiology explicating the specificity of biblical emotive meanings; (2) the analysis of the depicted biblical space in the emotive aspect; (3) the interpretation of biblical characters' activity as a cause of emotions attributed to God. The language analysis is carried out with the help of the notion of the emotional script. This notion helps to present the systemic description of emotion development that is the cause of its emergence and the corresponding response. The methodological approaches employed in the study include the definitional, contextual, emotive, and linguastylistic analyses, with reference to the historical and cultural context. The study results in classifying the following types of lexemes: 1) representing the cause of emotions attributed to God; 2) representing emotions attributed to God; 3) representing the biblical space perceived by characters as a 'reaction' to emotions attributed to God. Proceeding from the theandric nature of Jesus Christ, His depicted emotions are treated as a manifestation of His human nature. The study has allowed the author to give linguistic substance to one of the antinomies of Christian understanding of God and to project a new prospect of further linguistic research on Christian dogmata from an emotive perspective.

It is only logical that the conclusive contribution by Lara Sinelnikova puts the final touch to the questions discussed. Lara Sinelnikova's contribution delves into the conceptual environment of the frontier discourse in the humanities and, thus, finalizes the discussion of the problems touched upon in the current issue. The author argues that frontier concept has been familiar to scholars for a long time and its main characteristics, including its flexible borders, its conceptualization as a zone of space development characterized by uncertainty and instability, proved their importance for understanding and describing the current state of the environment in its social, cultural, communicative and linguistic indicators. The interdisciplinary (transcendental) potential of a frontier is realized in a complementary combination of natural sciences and humanities. The author aims at justifying the scientific integrity of the term 'frontier discourse', whose conceptual environment is created through two overlapping multi-layer phenomena: frontier and discourse. The article names the vectors of expanding the interdisciplinary potential of frontier under the conditions of a discourse approach. 
Frontier as a flexible border is presented in the internet communication, the sociocultural space of the modern city, in the daily behavioural norms of the elite, in the in-family relations and in many other conceptual spheres, whose list remains open due to the ontological features of the concept in question. Based on the examples from literature, the author demonstrates the role of the frontier modus in the interpretation of literary texts, whose plot, style and images are projected onto national history, culture, mentality in their by-border characteristics. Such frontier features as instability, its ability to create an interaction zone, which, under certain conditions, can lead to integration, are important for understanding the problems of modern language, speech and genre norms. The by-border territory is a place of accumulating violations of traditional norms and the material necessary to forecast the arising norm changes. The transformation of traditional genres and the formation of new ones also take place on the frontier territories. It is concluded that frontier discourse ensures the understanding of norm shifts in genre-stylistic characteristics.

The current volume contains two reviews on the issues closely connected with the topic under study. Etsuko Oishi reviews the book edited by well-known scholars of the theory of politeness and impoliteness Jonathan Culpeper, Michael Haugh and Dániel Z. Kádár (2017) The Palgrave Handbook of Linguistic (Im)politeness. In her review she underscores a desired balance between theory and application which is achieved by the contributors. The book unfolds the concept of impoliteness and brings a new perspective to the (im)politeness research: impoliteness as well as politeness manifests as facework strategies achieved discursively.

Marianna Ryshina-Pankova reviews the book edited by two prominent researchers of discourse and emotions J. Lachlan Mackenzie and Laura Alba-Juez (2019) Emotion in Discourse. This collection of articles instantiates what has been called the "emotional turn" in the human sciences and specifically in the study of language (see also Alba-Juez \& Larina, 2018, a special issue of this journal devoted to this theme). The volume focuses on the crucial importance of emotion in human communication and on the construal of emotions through language. Presenting the latest theoretical and empirical research on this matter, the book aims to provide a detailed account of the interaction of emotion, language, language proficiency, culture, and discourse.

\section{Discussion and outlook}

The emergence of discourse analysis stems from the idea to explore a human being in their social environment. "Discourse analytical approaches take as their starting point the claim of structuralist and poststructuralist linguistic philosophy, that our access to reality is always through language" (Jørgensen \& Phillips 2002: 8 ). With discourse analysis prescriptive and normative linguistics yielded its way to investigating language in use as the main prerogative and indisputable priority of linguistic studies. This paradigm has not exhausted itself; it still has a lot to explore 
to answer the eternal question of linguistics, how the human language functions when a human being uses it to achieve certain communicative aims. The current issue testifies that "discourse analysis is in constant evolution, and continues to expand in the range and scope of its research activities" (Ponton \& Larina 2017: 12) and we cannot but agree more. Linguists are still elaborating and substantiating a full integrative framework of the theory of discourse with many variables falling into the picture.

\section{$\mathbf{R U}$}

Представить себе мир без дискурса - это все равно, что представить себе мир без языка, то есть представить что-то невообразимое. ${ }^{1}$

(He 2003: 428)

\section{1. Введение}

В центре внимания этого выпуска - дискурс и то, как homo loquens, человек говорящий, выстраивает его в различных сферах человеческой деятельности. Авторы выпуска отвечают на вопрос о том, как язык, культура и идеология переплетаются в различных дискурсивных практиках и как эти практики формируются людьми, представляющими разные культуры, идеологии и социальные образования. Это не первый выпуск нашего журнала, посвященный дискурсу и дискурсивным практикам (см. Выпуски 2006, 4; 2017, 1; $2018,1 ; 2019,4)$, и на это есть веская причина. Дискурс - это явление, включающее все формы использования языка, что, собственно, и делает его единственным известным реальным лингвистическим объектом (Кибрик 2009: 1). Несмотря на то, что дискурсу посвящены многочисленные издания (Карасик 2002, Blommaert 2005, Fairclough 1992, 2003, Gee 2007, Johnstone 2018, Kalyango Jr. \& Kopytowska 2014, Schiffrin 1995, van Dijk 2006, 2009, 2011 и многие др.), он не теряет своей привлекательности для лингвистов по ряду важных обстоятельств. Дискурс позволяет исследователям сосредоточить свои усилия на человеке, вовлеченном в любой вид деятельности или взаимодействия. Прежде всего, в дискурсивных исследованиях говорящие приобретают “осязаемость" и конкретность как биологические, социальные, культурные, этнические, профессиональные идентичности. Как следствие, понимание значимости всех типов окружения, которые участвуют в производстве речи, привело к осознанию созидающей роли экстралингвистических факторов в использовании языка в целом. Дискурс позволил объединить «язык, действие, взаимодействие, ценности, убеждения, символы, объекты, инструменты и местопребывание таким образом, чтобы другие распознавали вас как особый тип того, кто (идентичность) участвовал в определенном типе того,

\footnotetext{
1 Здесь и далее перевод наш (М.Б., С.И.)
} 
что (деятельность), здесь и сейчас происходит» (Gee 1999: 27). Таким образом, le langage, эфемерное и требующее большего обоснования понятие, выдвинутое Ф. де Соссюром, приобрело наполненность и необходимую для лингвиста реальность.

\section{2. Основные принципы и цели теории дискурса}

В течение нескольких десятилетий лингвисты сосредоточивали свои усилия на структуре языка (la langue, по Соссюру), пока не стал очевидным тот факт, что лингвистика не может оставаться в этих жестких границах (Yule 1999: 139-140). Сначала завораживающий эффект языка в его функционировании (language in use) заставил ученых переключить свое внимание на речь (la parole, по Соссюру). Затем совокупность различных факторов, в том числе появление термина «дискурс» в работе Зеллига Харриса в 1952 году (Harris 1952), революция Хомского в лингвистике с его акцентом на competence vs performance (Chomsky 1965), изучение дискурса французскими учеными (Foucault 1981, 1994), и это далеко не полный перечень движущих лингвистику XX в. сил - привело к пониманию дискурса как результата теснейшего взаимодействия двух миров - языка и реальности (Foucault 1994), которые оказываются опосредованными деятельностью человека говорящего (Hagege 1985).

Всестороннее изучение дискурса началось с поиска учеными универсального определения этого сложного и многомерного по своей природе явления. В этом отношении восемь подходов к определению дискурса, изложенных П. Серио (Серио 1999: 25-27), все еще актуальны и обладают объясняющей силой - начиная с интерпретации дискурса как эквивалента соссюровского la parole и включая формулировку, содержащую все дискурсно-обусловленные ограничения на порождение текста (там же: 26-27). В конечном итоге интерпретация дискурса предполагает деятельность человека, направленную на создание мысли в словесной форме. При таком подходе на первый план выходят обстоятельства бытования дискурса и индивид, бытующий в этом дискурсе и/или связанный с ним. Как следствие, интерес вызывает изучение разнообразных факторов, которые взаимодействуют в рамках дискурса, формируя и форматируя его по образу и образцу говорящего. Именно человек стал центром лингвистической теории дискурса, при этом дискурс понимается как основное проявление человека в рамках производимой им деятельности и в совокупности со всеми отношениями, которые в этой деятельности возникают. Взаимоотношения между людьми, языком и культурой определяют человека как существо биологическое, социальное и культурное. При этом все эти ипостаси человека тесно связаны друг с другом и составляют единое нераздельное целое. Биологические характеристики людей, определяемые эволюцией и генетическими данными, постепенно трансформируются в процессы аккомодации и ассимиляции и изменяются посредством социаль- 
ного взаимодействия и социализации, превращая людей в социальные и культурные идентичности (Dolník 2015). Осознание того, что люди как биологические, социальные и культурные существа используют язык в качестве посредника во всей своей деятельности, побуждает лингвистов изучать язык в различных контекстах, что, по их мнению, поможет развязать этот гордиев узел. Заявление Дэвида Нунана (Nunan 1993) о том, что «дискурс объединяет язык, человека, производящего язык, и контекст, в котором этот язык используется» (Nunan 1993: 6-7), разделяют все дискурсологи. Исследователи сходятся во мнении, что термин «дискурс» используется при интерпретации коммуникативного события в контексте (Dijk 2009: 1). Таким образом контекст приобретает концептуальное значение для дискурсивного анализа (Нефедов, Чернявская 2020). Контекст как «набор соответствующих свойств коммуникативных ситуаций речевого взаимодействия» (Dijk 2009: VII) относится к ситуации порождения и бытования дискурса. В свете этого понимания дискурс «относится к набору норм, предпочтений и ожиданий, который пользователи языка имеют в своем распоряжении и изменяют при создании и осмыслении языка в контексте» (Saville-Troike 1994: 358).

Традиционно лингвисты выделяют два типа контекста. Первым из них является языковой или словесный контекст (также называемый микроконтекстом или со-текстом), то есть язык, который окружает или сопровождает анализируемый фрагмент дискурса. Второй - это неязыковой, невербальный или эмпирический контекст (также называемый макроконтекстом), в котором дискурс «происходит». Он испытывает формирующее влияние ряда факторов, включающих тип коммуникативного события (например, шутка, рассказ, лекция и т.д.), тему, цель события, окружение, участников и отношения между ними, а также фоновые знания, лежащие в основе коммуникативного события (Nunan 1993: 7-8). Как указывает И. Кечкеш (Kecskes 2014), в лингвистике «контексты обычно относятся к любому из факторов - лингвистическому, эпистемологическому, физическому, социальному, которые влияют на фактическую интерпретацию знаков и выражений» (Kecskes 2014: 35). Он предлагает различать предшествующий контекст (prior context), который находится в нашем сознании, и фактический ситуативный контекст, подчеркивая при этом, что «значение является результатом взаимодействия предшествующего опыта и текущего, фактического ситуативного опыта, и оба имеют социокультурный характер» (там же: 129).

Дискурс как использование языка в различных контекстах (ситуативный, географический, исторический, структурный, институциональный) также толкуется как трехмерное образование (текст, дискурсивная практика и социальная практика) (Fairclough 1992). Как социальная практика дискурс представляет собой сущность, встроенную в социальный и исторический контекст. Более того, впоследствии он участвует в социальном конструировании реальности и отвечает за социальное моделирование сообщества и создание социальных идентичностей, расширение знаний, формирование социальных 
отношений и создание сложных дискурсивных практик и дискурсивных конвенций (Resta 1998, van Dijk 2006).

Другим важным открытием, которое пришло с исследованиями дискурса, стало понимание тесной связи познания и дискурса. Стало ясно, что дискурс существует между мыслью и реальностью (Williams 1999: 23). Когнитивное прочтение теории дискурса предполагает, что люди мысленно «схватывают» окружающее их пространство со всеми отношениями и интегрируют все это вместе взятое в концепции, системы и отношения, то есть производят операцию концептуализации. Концептуализация может пониматься как восприятие, сегментация, спецификация и категоризация данных, относящихся к материальному и абстрактному миру, и последующая обработка их в мышлении и на языке. В отдельных лингвокультурных сообществах эти процессы происходят в определенных интерпретационных рамках, регулируемых интернализованными культурными закономерностями и соглашениями. Таким образом, в разных культурах люди по-разному схематизируют свой опыт и знания о мире. В результате языки различаются по «накопленным декларативным знаниям <...> и культурно-обусловленным схемам» (Kecskes \& Papp, 2000), иными словами, языки становятся и являются социально и культурно встроенными объектами.

Не будет преувеличением сказать, что к началу XXI века дискурс-анализ стал доминирующей парадигмой, охватывающей все гуманитарные науки, своеобразным духом времени, air du temps, в терминах Патрика Серио (Sériot 2012: 18). Представители разных лингвистических школ пытались описать формальные и функциональные особенности дискурса (Schiffrin 1994). Позже к этим двум добавилось третье измерение дискурса, а именно описание топосов, лежащих в основе определенных типов дискурса (Добросклонская 2014: 182). Таким образом, дискурс стал объектом анализа, объединяющим гуманитарные науки в их поисках семиотически выраженных (Fairclough 2004: 225226), социально-психологических, социологических, антропологических моделей (Dijk 2009) воспроизведения социальной идентичности.

\section{3. Современные вызовы теории дискурса}

Современные исследования лингвистического дискурса развиваются в нескольких направлениях, что обусловлено сложным характером изучаемого явления. Ученые пытаются достичь большей точности в определении объекта и предмета теории дискурса. Еще одной проблемой является разработка надежных методов анализа, которые могут быть использованы в лингвистике для изучения данной предметной области, для описания типов дискурса и дискурсивных практик, востребованных для поддержания существующих или возникающих социальных отношений.

В соответствии с социально-философским пониманием дискурса первоначально лингвисты обратились к тем сферам общения, в которых осуществляется постоянное воспроизводство власти и господства в обществе (van Dijk 
2011: xvii). Это были политический дискурс (van Dijk 2006, Fairclough 1989), новостной (Fowler 1991, van Dijk 1988), дискурс масс медиа (van Dijk 1985), юридический дискурс (Goodrich 1987). Очень скоро перечень дискурсов, которые исследовали лингвисты, вырос, и его дополнили рекламный (Cook 1992), маркетинговый (Skålén et al. 2008,), медицинский (Good, DelVecchio Good 1981, Locher 2017), учебный (Christie 2002), академический (Hyland 2009) дискурсы. Все эти типы дискурса остаются в поле внимания исследователей, причем объем работ только увеличивается, когда дело доходит до политического (например, Beard 2000, Chilton 2004, Ponton 2016, Солопова, Чудинов 2018, Шейгал 2004), массмедийного (например, Добросклонская 2014, Озюменко 2017, Bell \& Garett 1992, Dubrovskaya, Kozhemyakin 2016, Larina, Ozyumenko, Ponton 2019, Matheson 2005, Talbot 2007), новостного (Bednarek 2006, Montgomery 2007), юридического / судебного (например, Дубровская 2017, Gotti \& Williams 2003), религиозного (например, Бобырева 2007, Найденова 2018, Wierzbicka 2018). Более того, дискурс-анализу подвергаются новые области человеческой деятельности - в данном случае речь идет о таких типах дискурса, как интернет-дискурс (Crystal 2010), дискурс развлекательный / досуговый, именуемый также консьюмеристским (Fullagar 2002, Молодыченко 2016), лайфстайл-дискурс (Иванова 2019, Молодыченко 2020), туристический дискурс (Jaworski, Thurlow 2010), гендерный дискурс (Mills 2003), спортивный дискурс (Кошкарова 2019), гастрономический дискурс (Олянич 2003), урбанистический (Леонтович 2019) и многие другие. Все это свидетельствует в пользу утверждения О.С. Иссерс о том, что составить полный список типов дискурсов не представляется возможным (Иссерс 2011: 227). Более того, исследователи отмечают тенденцию к интеграции и гибридизации дискурсов (Иванова 2017).

Теория дискурса стала перспективной основой для многих направлений лингвистического анализа. Одной из этих новых областей, которые подверглись экспансии теории дискурса, стало изучение эмоций (например, Шаховский 2015, 2018, Alba-Juez \& Larina 2018, Mackenzie \& Alba-Juez 2019 и многие другие). Лингвисты увидели связь между эмоциями и определенными типами контекста, порождающими «процесс мультимодального дискурса, который пронизывает все уровни языка, но также проявляется в невербальных способах, представляя различные стадии и формы (под влиянием таких переменных, как прагматические ожидания или общие знания), по мере того, как дискурсивная ситуация и взаимодействие изменяются и развиваются» (Mackenzie \& Alba-Juez 2019: 18). Дискурсивный подход к эмоциям позволил показать это явление как динамическую, дискурсивно-прагматическую сущность. Этот «эмоциональный поворот» неизбежно вызвал некоторые изменения предметной области дискурс-анализа - убеждение перестало быть определяющим фактором для определения объекта исследования теории дискурса, дискурс способствует пониманию того, как человек конструирует свою 
социальную идентичность в различных типах взаимодействия (e.g. Langlotz \& Locher 2017, Larina et al 2017 и др.).

Важной областью исследований, граничащей с анализом дискурса, является коммуникация. Сферы, типы и формы общения, с одной стороны, и типы дискурса, с другой - что у них общего и каковы их отличительные особенности? Интересно, что дискурсивный анализ породил термин, который объединяет эти два понятия: речь идет о дискурсивной практике. Диапазон интерпретации этого термина, восходящего к работам М. Фуко (Foucault 1981), варьируется от «производства, распространения и потребления текстов» (Fairclough 1992: 5, 73, 2010) до «практик (или операций) дискурсов, означающих накопление знаний» без какой-либо ссылки на лингвистические практики или использование языка (Bacchi \& Bonham 2014: 173). Несмотря на это противоречие, большинство лингвистов следуют «лингвистическому повороту», согласно которому дискурсивные практики являются лингвистическим отражением социальных практик, определяемых как «относительно стабилизированная форма социальной активности» (Fairclough 2001: 231). Поэтому ученые подходят к рассмотрению дискурсивных практик как механизмов дискурсивного построения различных типов отношений, начиная с распределения власти и включая разнообразные типы коммуникации. Таким образом, изучение дискурса оказалось тесно связанным с изучением общения и его различных коммуникационных стратегий.

Еще одна область расширения области дискурс-анализа - это изучение стратегий не / вежливости, превращающих их в дискурсивные практики. Дискурсивный подход к вежливости (Eelen 2001, Watts 2003, Mills 2003) дал новый импульс развитию теории вежливости, значительно расширив ее диапазон. Наибольшая значимость дискурсивного поворота заключалась в том, чтобы «напомнить нам об оценочном и относительном характере таких понятий, как невежливость или вежливость, о важности, которую эмоции играют в оценках, и сделать вывод о связи конструирования идентичности с этими процессами оценки» (Locher \& Larina 2019: 875). Изучение невежливости также вытекает из дискурсивного подхода к языку (например, Bousfield 2008, Bousfield \& Locher 2008, Culpeper 2011, Garcés-Conejos Blitvich \& Sifianou 2019). Как справедливо утверждает Калпепер (Culpepper 2011), невежливость является важным аспектом социальной жизни и играет центральную роль во многих дискурсах, которые редко описываются подробно (Culpeper 2011: хіii). Как вежливость, так и невежливость включают изучение конкретного коммуникативного поведения в социальном взаимодействии с акцентом на контекст (например, Bousfield 2008, Fernández-Amaya 2019).

Помимо перечисленных проблемных зон, необходимо обратиться к еще одному вопросу, который связан с проблемой определения места дискурса по отношению к традиционным сферам лингвистического анализа. Дискурс, понимаемый как когнитивная сущность на уровне гештальта (поскольку для 
него присуща некая инвариантная модель и его характеризуют прототипические свойства), должен найти свое место по отношению к давно существующим и устоявшимся в лингвистической науке понятиям. Так, неоднократно поднимался вопрос о взаимоотношении дискурса и жанра как набора ожиданий, которые выстраивает зрелый читатель, как некоей автономной системы со своими собственными кодексами и конвенциями (Corbett 2009: 287). В ходе данной дискуссии звучали голоса о том, что лингвистика должна избавиться от понятия «жанр» и заменить его термином «дискурс». Потребовалось время, чтобы выработать сбалансированный подход к решению о совместимости данных терминов. В настоящее время актуальность жанровых исследований в рамках дискурс-анализа (например, Дементьев 2016, Иванова 2017, Cap \& Okulska 2013, Fuentes Rodríguez \& Álvarez-Benito 2016, GarcésConejos Blitvich, 2010) не вызывает сомнений (Dijk 2009: 8). При этом необходимо отдавать себе отчет в том, что эта, казалось бы, всего лишь терминологическая проблема отражает трудности изучения единиц, превышающих предложение и относящихся к описанию речи и речевой деятельности.

Расширение предмета и диверсификация объекта анализа поставили перед лингвистами, занимающимися теорией дискурса, еще одну проблему, касающуюся выбора методов и доказательства достоверности полученных результатов. Нет необходимости говорить, что степень остроты и серьезность проблемы методологии обусловлены многомерностью дискурса и его особым статусом в гуманитарных науках. Общеизвестно, что лингвистическая теория дискурса стала развитием идей дискурс-анализа, которые совершили прорыв в гуманитарных науках в 1960-е годы. Благодаря французскому структурализму дискурс вошел в научно-исследовательскую практику как объект социологии. Совершенно естественно, что первоначально к анализу дискурса применялись социологические методы. Лингвистической теории дискурса потребовалось время, чтобы выработать свой собственный подход к исследованию. Значительным шагом в этом направлении послужили книги (Jørgensen \& Phillips 2002, Titscher et al. 2000), авторы которых ставили цель упорядочить методологическую базу лингвистической теории дискурса как сравнительно молодого направления языкознания.

Еще одна трудность методологического характера связана с междисциплинарным статусом теории дискурса. Теория дискурса, или дискурс-анализ, приоритизирует язык, общество и человека, а это, в свою очередь, требует исследований на стыке различных областей знаний. Соответственно, теория дискурса использует междисциплинарные методы анализа, к примеру работу с корпусами (Чернявская 2017, 2018), для решения поставленных задач. Именно междисциплинарность является неотъемлемым принципом дискурсанализа, критического дискурс-анализа (CDA) или исследований критического дискурса (CDS). Й. Унгер (Unger 2016) считает, что в этом подходе проявляется естественная потребность лингвистов преодолевать «иногда устойчивые и жесткие дисциплинарные границы лингвистики» (Unger 2016: 2). 
Этот подход используется при анализе контекста на уровне теоретического осмысления, выбора методов и сбора эмпирических данных в рамках дискурс-анализа или CDA. При этом используются данные разнообразных научных областей (таких как социология, психология, когнитивная наука, философия и т.д.). Дискурс-анализ, кроме того, применяет методологию различных направлений лингвистических исследований (лингвистика текста, корпусная лингвистика, этнография и т. д.) и исследует все, что связано с использованием языка (Unger 2016: 2).

Все эти проблемы активно обсуждаются в рамках теории дискурса и смежных с нею областей научного знания, о чем свидетельствует как большое количество соответствующих публикаций, так и количество конференций по этой актуальной тематике. Так, идею к созданию данного номера дала конференция "Язык в современных дискурсивных практиках", которая состоялась в Москве, в РУДН, в Институте современных языков, межкультурной коммуникации и миграции 22-23 октября 2019 года. Выступления пленарных докладчиков, среди которых были Мириам А. Лохэр (Базельский университет, Швейцария), Лаура Альба-Хуэс (UNED, Мадрид), Даниэль Кадар (Академия наук Венгрии и Далянский университет иностранных языков), Магдалена Била и Ингрида Ванькова (Университет Прешова, Словакия), Моника Копытовска (Университет Лодзи, Польша), показали, что исследование дискурсивных практик проводится на базе самых разных типов дискурса и касается выражения эмоций, вежливости и невежливости, языка вражды и др. Проведенные в рамках конференции дискуссии еще раз подтвердили стремление исследователей найти закономерности функционирования языка в обществе в связке с человеком говорящим, думающим, чувствующим.

\section{4. Авторы этого выпуска}

Наш выпуск выходит в непростое время, и мы благодарны всем тем, кто продолжает работать и делиться с нами своими идеями, мыслями, в том числе далеко выходящими за рамки лингвистики. Этот выпуск начинается с обращения Анны Вежбицкой ко всем нам, объединенным в нашей общей борьбе против пандемии, которая приобрела форму глобального социального события. Анна Вежбицкая делится семью важными мыслями, которые она выражает при помощи разработанного ею Естественного Семантического Метаязыка (Goddard \& Wierzbicka 2014, Wierzbicka 1996), позволяющего одинаково точно передавать мысли и чувства на всех языках мира. Она смогла найти правильные и понятные слова, которые звучат как своего рода ориентиры. Мы можем только надеяться, что они помогут нам справиться со сложностями и трудностями этого периода, найти новые перспективы и оставаться позитивными.

Все работы, представленные на страницах настоящего специального выпуска, обращены к анализу дискурсивных практик. Исследуя в различных ракурсах особенности взаимодействия языка, культуры и идеологии сквозь 
призму дискурса, авторы тем самым расширяют и уточняют наши знания о происходящих на микро- и макроуровнях процессах общественной жизни. В основе представленных исследований лежит идея о том, что дискурс сосредоточен на социальной конструкции значения (Williams 1999: 5).

Выпуск открывает статья Анны Вежбицкой, в которой она анализирует, как люди, говорящие на различных европейских языках, обращаются к Богу. Каждая лингвокультура имеет свои характерные способы обращения к Богу, закодированные в определенных словах, фразах и грамматических формах, которые отражают и формируют привычные способы мышления говорящих о Боге и отношения к Богу. Зачастую они также отражают и другие аспекты культурной памяти и исторического опыта человека говорящего. В связи с этим автор прибегает к культурному комментарию о более широких исторических явлениях. Цель, которую ставит перед собой автор, соответствует пониманию того, что, будучи носителями культуры, люди проявляют себя через стандартизированные манеры аккомодационного поведения. Результаты исследования показывают, что каждый европейский язык предлагает своим пользователям различные варианты обращения к Богу. Некоторые из этих опций являются общими; другие характеризуются лингвокультурной уникальностью. Тем не менее, как утверждает автор, причины различий всех этих обращений еще предстоит изучить.

В ходе социализации люди развивают различные (словесные) модели поведения и различные способы интерпретации мира, что приводит к появлению множества языковых сообществ (Dolník, 2015). В трех последующих статьях текущего номера рассматривается связь идеологии, идентичности и языка в различных дискурсивных практиках в разных языковых сообществах. Идеология характеризует социальные группы, определяет, но и определяется их социальными практиками.

Язык окружает нас, пронизывая нашу общественную и личную жизнь, материализуясь в форме речевых звуков и отображаясь в текстах в виде вывесок магазинов, объявлений, плакатов, рекламных лозунгов и т.д. Мартин Пютц исследует языковой ландшафт Камеруна и делится своими размышлениями о языковой политике и идеологии. Он останавливается на языковом ландшафте как на относительно недавней области исследований, которую он определяет как визуальную представленность языков в публичном пространстве. Языковой ландшафт Камеруна репрезентирован английским, французским, пиджин-английским, камфранглийским и, в меньшей степени, коренными африканскими языками. Исследование Мартина Пютца показывает, что область языковых ландшафтов может выступать в качестве отражения языковых иерархий, идеологий и актов сопротивления в многоязычных и многокультурных сообществах. Кроме того, в Камеруне языковой ландшафт почти исключительно сосредоточен на доминирующем статусе и роли одного отдельного языка, то есть французского и, в меньшей степени, английского, по- 
этому англоговорящие граждане чувствуют себя в определенной степени маргинализированными. Несомненный интерес данной публикации связан с используемой автором методологией: в работе анализу подвергнуты более 600 лингвистических токенов (цифровых фотографий), которые были собраны в различных общественных местах, главным образом в и вокруг столицы Камеруна Яунде.

Как известно, изучение дискурса началось со стремления исследовать политику и власть, выраженную в языке и посредством языка (Фуко 1981: 1994). Это направление дискурсивных исследований не теряет своей актуальности и пополняется новыми публикациями, о чем свидетельствует и статья Стефани Муди и Зохрэ Еслами. Они обращаются к проблематике политического дискурса в той части, которая касается особенностей кодовых переключений и выражения идеологии. Авторы сосредоточивают свое внимание на механизмах манипулирования, внушения и убеждения, присущих языку. Они изучают дискурсивные практики, связанные с переключением языковых кодов в процессе речевой деятельности, в рамках которых дву- и многоязычные участники коммуникации гибко используют весь свой лингвистический репертуар для создания смысла. Переключение кодов, фиксируя историческую, политическую и социальную встроенность языковых практик в речевую деятельность человека в социуме, свидетельствует о том, что эти дискурсивные практики напрямую связаны с идеологиями. Основываясь на концепции языковых идеологий, авторы ставят своей целью определение того, как кодовые переключения использовались сенатором Кейном в политическом дискурсе и как эти случаи варьировали в зависимости от контекста каждой речи. Исследование показывает, как можно использовать кодовые переключения для формирования политического капитала, создания альянсов и демонстрации культурного сходства между белыми политиками и их дву- и многоязычными избирателями. Представленное исследование служит иллюстрацией глубокого замечания Т. ван Дейка о том, что «идеологии выражаются и, как правило, воспроизводятся в социальных практиках их членов и, в частности, приобретаются, подтверждаются, изменяются и увековечиваются посредством дискурса» (van Dijk 2006: 115).

Проблематика социальной идентичности в дискурсивных практиках раскрывается в работе Магдалены Била, Алены Качмаровой и Ингриды Ваньковой. Авторы сопоставляют две лингвокультуры сквозь призму социального дейксиса. Хорошо известен тот факт, что в большинстве языков, в основном европейских, передача социального дейксиса колеблется между двумя полюсами, которыми служат морфологические средства, формы $m b l$ и $B b l$. Авторы обращаются к исследованию словацкого и английского языков, которые, соответственно, различаются по наличию эксплицитных маркеров $m b l / B b l$. Весьма интересна разработанная авторами пошаговая методика исследования. Уникальность английской и словацкой культурной идентичности 
и / или дискурсивная практика соответствующей культуры в отношении выражения социальной дистанции рассматриваются в два этапа. Во-первых, связанные понятия (культурная идентичность, социальная дистанция, формы $m b l / B b l)$ подвергаются анализу посредством схемы концептуализации (установление кадра, кодирование / предварительное понимание, контекстуализация / значимость и конфигурация кода). Процесс концептуализации, включающий набор принципов, дал результаты, на основе которых были разработаны вопросники для испытуемых. Результаты исследования показывают, что концептуализация $m b l$ vs $B b l$, иначе говоря, неофициального в отличие от официального, может проистекать из концептуализации социальной дистанции с точки зрения набора принципов, концептуализации конкретного принципа с точки зрения типов отношений, концептуализации типа отношений с точки зрения конкретной культуры и концептуализации типа культуры с определенной спецификой через морфологические средства ( $m b l$ или $B b l)$.

Дискурсивные практики маркетингового дискурса веб-сайтов выступают объектом исследования, представленного в статье Н.В. Соколовой. Работа заслуживает особого внимания тех, кто интересуется сложной проблемой методологии анализа мультимодальности в дискурсе. Автор выстраивает свой мультимодальный анализ, опираясь на положения критического дискурс-анализа, прагматики и лингвистики текста. Комплексный подход позволяет учесть ряд параметров: дискурсопорождающую интенцию адресанта, функцию дискурса, реализацию категорий в вербальном контенте мультимодального дискурса и использование аудиовизуальных приемов в невербальном контенте, глобальную идеологему, или ключевую идею, дискурса, а также адресата. Дискурсопорождающей интенцией является побуждение потребителя к приобретению ИТ-решения, при этом дискурс реализует воздействующую функцию. Текстовое наполнение веб-сайтов рассматривается в рамках таких категорий, как тема (терминология сферы информационных технологий); тональность (положительно окрашенная лексика; повелительное наклонение); хронотоп (экономия времени для решения глобальных задач в рамках всего предприятия). Анализ показывает, что в рамках маркетинговых дискурсов трех компаний используются сходные антитезы (проблемы работы с большим количеством данных vs. одно ИТ-решение, ситуация до и после, старое vs. новое), аналогична и реализация категорий и аудиовизуальных приемов, что может потребовать дальнейших исследований маркетингового дискурса с точки зрения восприятия его специфичности клиентами.

Дискурсивные практики, связанные с жанровыми разновидностями текстов, репрезентирующих дискурс, являются объектом анализа следующей публикации. С.В. Иванова и Г.Ш. Хакимова исследуют слухи о знаменитостях как жанр в англоязычном дискурсе СМИ. Цель исследования авторы видят в выявлении специфики медиаслухов как речевого жанра англоязычной медиакоммуникации. Соответственно, авторы обращаются к содержательному (тематическому) и формальному (структурно-композиционному) 
уровням исследования. В работе выявляются дистинктивные признаки изучаемого жанра, включающие установленные для него ограничения, и диапазон обсуждаемых тем. Анализ эмпирического материала свидетельствует, что тематически изучаемые тексты отличаются широким диапазоном топосов, охватывающих как публичную сферу (социальные взаимодействия), так и приватную, зачастую интимную область жизни знаменитостей, с явным предпочтением последней. Доминантными дискурсивными характеристиками репрезентаций исследуемого текстотипа являются сенсационность и скандальность. В структурном плане дискурс светских слухов конституируется текстами, облеченными в различные журналистские формы: от жанров информационного блока до публицистических вариаций категории features, которые используются авторами в качестве средства конструирования реальности, связанной с культурой селебрити. Информация, имеющая, по сути, тривиальный по содержанию и сомнительный в силу своей неподтвержденности характер, с помощью разнообразных языковых и текстовых ресурсов камуфлируется под сведения, обладающие высокой степенью достоверности и эпистемической ценности. Полученные результаты свидетельствуют о существовании в рамках обширного коммуникативного пространства массмедиа специфического типа дискурса, гибридного по своей природе и практически не поддающегося верификации.

А.А. Романов и О.В. Новоселова раскрывают прагматическую эффективность реализации высказываний-угроз (менасивных высказываний или менасивов) в политической коммуникации, а именно авторы ставят своей целью установить целесообразность использования угрозы в предвыборных программах с тем, чтобы побудить избирателей проголосовать за конкретного политика. Авторы анализируют высказывания-угрозы, реализованные в предвыборных программах кандидатов на пост Президента Российской Федерации в 2018 году. При анализе применяется инструментарий теории речевой деятельности, теории речевых актов и психосемантики. В ходе исследования выделено 18 адресатных разновидностей высказываний-угроз, которые обладают определенным прагма-эмоциональным воздействием на избирателей и характеризуются различной частотностью употребления в предвыборных программах. Полученный результат свидетельствует о недостаточном знании авторами предвыборных программ предпочтений массового избирателя, его эмоционального состояния и переживаний. Это обусловливает ориентированность менасивного воздействия на широкий круг потенциальных избирателей. Авторы приходят к выводу, что политики целенаправленно предпочитают использовать высказывания-угрозы, эксплицирующие последующий негативный эффект для нефокусной аудитории, пытаясь таким образом завоевать внимание и голоса избирателей. Кроме того, проведенный анализ показывает, что использование политиком четырех разновидностей высказываний-угроз с различной адресатной направленностью консеквентного 
компонента является прагматически эффективным инструментом воздействия в контексте российского предвыборного дискурса 2018 года.

Статья С.М. Пашкова раскрывает проблематику изучения эмоций и их отражения в дискурсивных практиках в рамках религиозного дискурса. В результате анализа автор классифицирует языковые репрезентанты эмоций, атрибутируемых Богу библейскими персонажами. На основе изучения богословского понимания антиномии «неизменность Бога - эмоции Бога» в статье обосновывается (1) введение термина «атрибуция эмоций» в понятийнотерминологический аппарат лингвистики эмоций, эксплицирующего специфику библейских эмотивных смыслов; (2) рассмотрение изображенного библейского пространства в эмотивном аспекте; (3) интерпретация изображенной деятельности библейских персонажей в качестве причины эмоций, атрибутируемых Богу. Языковой материал проанализирован с опорой на понятие эмоционального сценария, позволяющего представить системное описание развития эмоции, то есть причину ее появления и реакцию. Методы исследования языкового материала включают дефиниционный, контекстуальный, эмотивный и лингвостилистический анализы с привлечением факторов широкого историко-культурного контекста. В результате исследования автором установлены и систематизированы: 1) языковые средства, репрезентирующие причины эмоций, атрибутируемых Богу; 2) языковые средства репрезентирующие эмоции, атрибутируемые Богу; 3) языковые средства, репрезентирующие пространство, воспринимаемое библейскими персонажами как «реакция» на атрибутируемые Богу эмоции. Полученные результаты позволили наполнить языковым содержанием одну из антиномий христианского понимания Бога и наметить перспективу дальнейшего лингвистического исследования христианской догматики в эмотивном ракурсе.

Составители данного выпуска посчитали, что завершающей для этого журнала должна стать статья Л.Н. Синельниковой, которая тематически венчает представленную вниманию читателей коллекцию статей и выводит проблему дискурса и дискурсивных практик в сопредельные области научного знания. Данная публикация раскрывает меж- и трансдисциплинарные свойства дискурсивных исследований. Автор обращается к исследованию пограничных дискурсов и ставит своей целью обоснование научной состоятельности понятия фронтирного дискурса, концептуальная среда которого складывается в условиях наложения двух многоуровневых феноменов: дискурса и фронтира. Фронтир как подвижная граница представлен в интернет-коммуникациях, в социально-культурном пространстве современного города, в поведенческих нормах элиты, во внутрисемейных отношениях и многих других концептуальных сферах, список которых, по онтологическим признакам фронтира, принципиально открыт. В статье названы векторы расширения междисциплинарных возможностей фронтира в науке в условиях дискурсного подхода. Автор показывает роль фронтирного модуса в интерпретации художественных текстов, сюжет, стиль и образы которых проектируются на 
национальную историю, культуру, ментальность в их порубежных характеристиках (by-border characteristics). Нельзя не согласиться с автором, что такие признаки фронтира, как неустойчивость, способность создавать контактную зону (зону взаимодействия), при определенных условиях ведущую к интеграции, важны для понимания проблемы современной языковой, речевой и жанровой нормы. Территория порубежья (то, что находится между) является местом сбора нарушений традиционных норм и вместе с тем материалом для прогноза нарождающихся изменений нормы. Трансформация традиционных жанров и формирование новых также происходит на фронтирных территориях.

Текущий выпуск содержит рецензии двух изданий, тесно связанных с изучаемой тематикой и проблематикой. Эцуко Оиси рецензирует книгу, вышедшую под редакцией известных исследователей теории не/вежливости Дж. Калпепера, Майкла Хо и Даниела Кадара (Culpeper, Jonathan, Michael Haugh and Dániel Z. Kádár (eds.). 2017. The Palgrave Handbook of Linguistic (Im)politeness, London: Palgrave Macmillan). В своем обзоре рецензент отмечает желаемый баланс между теорией и практикой, который в полной мере удалось достичь авторам. Книга по-новому раскрывает концепцию невежливости: невежливость, как, собственно, и вежливость проявляются в стратегиях непосредственного общения, их можно достичь в рамках дискурса.

Марианна Рышина-Панкова рецензирует книгу, вышедшую под редакцией двух известных исследователей эмоций в дискурсе Дж. Лахлана Маккензи и Лауры Альба-Хуэс (Mackenzie, J. Lachlan and Laura Alba-Juez (eds.). 2019. Emotion in Discourse). Книга знаменует собой то, что в гуманитарных науках называют «эмоциональным поворотом», особенно в том, что касается изучения языка (см. также специальный выпуск этого журнала, посвященный данной теме - 2018,1). В книге раскрывается исключительная важность эмоций в общении между людьми и показано, как посредством языка и через язык создаются эмоции. Представляя последние теоретические и эмпирические исследования по этому вопросу, книга призвана дать подробный анализ взаимодействия эмоций, языка, владения языком, культурой и дискурсом.

\section{5. Обсуждение и перспективы}

Появление дискурс-анализа как направления научного поиска связано с осознанием необходимости исследовать главный объект гуманитарной науки - человека в его социальном окружении. Дискурс-анализ в качестве отправной точки базируется на утверждении структурной и постструктуралистской лингвофилософии о том, что мы всегда получаем доступ к реальности через язык (Jørgensen \& Phillips 2002: 8). Прескриптивизм и нормативность предшествующих этапов развития лингвистики уступили место исследованию языка в его непосредственном функционировании. Именно язык как он есть здесь и сейчас стал прерогативой и безусловным приоритетом 
лингвистических исследований начала XXI века. Современная исследовательская практика показывает, что эта парадигма далеко еще себя не исчерпала. Дискурс-аналитикам предстоит отвечать на вечные вопросы лингвистики о том, как функционирует человеческий язык, когда человек использует его для достижения конкретных коммуникативных целей в той или иной социальной среде. Публикации, которые вы найдете в настоящем выпуске, свидетельствуют о том, что «анализ дискурса находится в постоянной эволюции и продолжает расширяться в диапазоне и масштабах своей исследовательской деятельности» (Ponton, Larina 2017: 12), и мы не можем не согласиться с этим. Лингвисты все еще разрабатывают и обосновывают целостную в своей совокупной объяснительной силе, интегрированную с пограничными областями теорию дискурса, которая должна свести воедино многие переменные, чтобы они сложились в единую картину под названием «человек-языкобщество».

(C) Magdaléna Bilá and Svetlana Ivanova, 2020 (c)creative

This work is licensed under a Creative Commons Attribution 4.0 International License https://creativecommons.org/licenses/by/4.0/

\section{REFERENCES /СПИСОК ЛИТЕРАТУРЫ}

Alba-Juez, Laura \& Tatiana V. Larina. 2018. Language and emotion: Discourse-pragmatic perspectives. Russian Journal of Linguistics 22 (1). 9-37.

Alexander, Richard \& Arran Stibbe. 2014. From the analysis of ecological discourse to the ecological analysis of discourse. Language Sciences 41. 104-110.

Beard, Adrian. 2000. The Language of Politics. NY: Routledge.

Bednarek, Monika. 2006. Epistemological positioning and evidentiality in English news discourse: a text-driven approach. Text and Talk 26 (6). 635-660.

Bell, Allan \& Peter Garett. 1998. Approaches of media discourse. Oxford: Blackwell Publishers.

Blommaert, Jan. 2005. Discourse. Cambridge. Cambridge University Press.

Bacchi, Carol \& Jennifer Bonham. 2014. Reclaiming discursive practices as an analytic focus: Political implications. Foucault Studies 17. 173-192.

Bousfield, Derek. 2008. Impoliteness in Interaction. Amsterdam: John Benjamins Publishing Company.

Bousfield, Derek \& Miriam A. Locher (eds.). 2008. Impoliteness in Language. Studies on its Inter-play with Power in Theory and Practice. Berlin: Mouton de Gruyter.

Cap, Piotr \& Urszula Okulska. 2013. Analyzing Genres in Political Communication: Theory and Practice. John Benjamins Publishing.

Chernyavskaya, Valeria E. 2017. Metodologitscheskie vosmoznosti diskursivnogo analiza v korpusnoi lingvistike [Towards methodological application of discourse analysis in corpus-driven linguistics]. Tomsk State University Journal of Philology 50. 135-148. DOI: $10.17223 / 19986645 / 50 / 9$. 
Chernyavskaya, Valeria E. 2018. Diskursivnyy analiz i korpusnyye metody: neobkhodimoye dokazatel'noye zveno? Ob"yasnitel'nyye vozmozhnosti kachestvennogo i kolichestvennogo podkhodov [Discourse analysis and corpus approaches: a missing evidence-based link? Towards qualitative and quantitative approaches]. Voprosy Kognitivnoy Lingvistiki 2. 31-37. DOI: 10.20916/1812-3228-2018-2-31-37.

Chilton, Paul. 2004. Analysing Political Discourse: Theory and Practice. NY: Routledge.

Chomsky, Noam. 1965. Aspects of the Theory of Syntax. Cambridge, Mass.: M.I.T. Press.

Christie, Frances. 2002. Classroom Discourse Analysis. A Functional Perspective. London, New York: Continuum.

Cook, Guy. 1992. The Discourse of Advertising. London and New York: Routledge.

Corbett, James. 2009. Genre and Genre Analysis. In Jacob L. Mey (eds.), Concise Encyclopedia of Pragmatics. 2nd edn. Oxford: Elsevir Ltd.

Crystal, David. 2010. Internet Linguistics. London, New York: Routledge.

Culpeper, Jonathan. 2011. Impoliteness. Using Language to Cause Offence. Cambridge: Cambridge University Press.

Culpeper, Jonathan, Michael Haugh \& Dániel Z. Kádár (eds.). 2017. Palgrave Handbook of Linguistic (Im)Politeness. London: Palgrave.

Dementyev, Vadim. 2016. Speech genres and discourse: Genres study in discourse analysis paradigm. Russian Journal of Linguistics 20 (4). 103-121.

Dobrosklonskaya, Tatiana G. 2014. Massmedijnyj diskurs kak ob"ekt nauchnogo opisaniya [Mass media discourse as an object of scientific description]. Nauchnye vedomosti. Seriya Gumanitarnye nauki 13 (184). 22. 181-187.

Dolník, Ján. 2015. Človek - jazyk - kultúra. Kaligram.

Dubrovskaya, Tatiana. 2017. Metapragmatics of Administering Justice in Russian and English Judicial Discourse. Russian Journal of Linguistics 21 (1). 73-90.

Dubrovskaya, Tatiana \& Evgeniy Kozhemyakin. 2016. Media construction of Russia's international relations: specifics of representations. Critical Discourse Studies 14 (1). 90-107. DOI: 10.1080/17405904.2016.1196228.

Eelen, Gino. 2001. A Critique of Politeness Theories. Manchester: St Jerome.

Fairclough, Norman. 1989. Language and Power. London: Longman.

Fairclough, Norman. 1992. Discourse and Social Change. Cambridge: Cambridge Polity Press.

Fairclough, Norman. 2001. The dialectics of discourse. Textus 2 (14). 231-242.

Fairclough, Norman. 2003. Analysing discourse: Textual analysis for social research. London: Routledge.

Fairclough, Norman. 2010. Critical Discourse Analysis: The critical study of language. 2nd edn. Harlow: Longman.

Fairclough, Norman. 2014. Language and Power. 3rd edn. Routledge.

Fernández-Amaya, Lucía. 2019. Disagreement and (im)politeness in a Spanish family members' WhatsApp group. Russian Journal of Linguistics 23 (4). 1065-1087. DOI: 10.22363/2312-9182-2019-23-4-1065-1087.

Foucault, Michel. 1981. The Order of Discourse. In Robert Young (eds.), Untying the Text: A Post-Structuralist Reader, 51-78. Boston, London and Henley: Routledge and Kegan Paul.

Foucault, Michel. 1994. The Order of Things. An Archeology of the Human Sciences: A translation of Les Mots et les choses. New York: Vintage Books, a Division of Random House Inc.

Fowler, Roger. 1991. Language in the News. London \& New York: Routledge.

Fuentes Rodríguez, Catalina \& Gloria Álvarez-Benito. 2016. A Gender-based Approach to Parliamentary Discourse: The Andalusian Parliament. John Benjamins. 
Fullagar, Simone. 2002. Governing the healthy body: Discourses of leisure and lifestyle within Australian health policy. Health: An Interdisciplinary Journal for the Social Study of Health, Illness and Medicine 6 (1). 69-84.

Garcés-Conejos Blitvich, Pilar. 2010. A genre approach to the study of im-politeness. International Review of Pragmatics 2. 46-94.

Garcés-Conejos Blitvich, Pilar \& Maria Sifianou. 2019. Im/politeness and discursive pragmatics. Journal of Pragmatics 145. 91-101. DOI: 10.1016/j.pragma.2019.03.015.

Gee, James Paul. 2007. Introduction to Discourse Analysis: Theory and Method. New York and London: Routledge.

Goddard, Cliff \& Anna Wierzbicka. 2014. Words and Meanings: Lexical Semantics across Domains, Languages, and Cultures. Oxford: Oxford University Press.

Good, Byron J. \& Mary-Jo Del Vecchio Good. 1981. The Semantics of Medical Discourse. In Everett Mendelsohn \& Yehuda Elkana (eds.), Sciences and Cultures. Sociology of the Sciences a Yearbook. 5. Springer, Dordrecht.

Goodrich, Peter. 1987. Legal Discourse. London: Macmillan Press.

Gorter, Durk. 2006. Introduction: The Study of the Linguistic Landscape as a New Approach to Multilingualism. International Journal of Multilingualism 3 (1). $1-6$.

Gotti, Maurizio \& Christopher Williams. 2003. Legal Discourse across Languages and Cultures. Peter Lang.

Hagege, Claude. 1985. L'Homme de paroles. Paris: Fayard.

Harris, Zellig. S. 1952. Discourse Analysis. Language 28. 1-30.

He, Agnes Weiyun. 2003. Discourse Analysis. In Mark Aronoff \& Janie Rees-Miller (eds.), The Handbook of Linguistics. Blackwell Publishing.

Hyland, Ken. 2009. Academic Discourse: English in a Global Context. Continuum.

Issers, Oxana S. 2011. Diskursivnaya praktika kak nablyudayemaya real'nost' [Discursive practice as an observable reality]. Vestnik Omskogo universiteta 4. 227-232.

Ivanova, Svetlana V. 2017. Commencement Speech as a Hybrid Polydiscursive Practice. Russian Journal of Linguistics 21 (1). 141-160.

Ivanova, Svetlana V. 2019. Stylistics and rhetoric of lifestyle discourse. Professional Discourse \& Communication 1 (2). 8-21. DOI: https://doi.org/10.24833/2687-0126-2019-1-2-8-21.

Jaworski, Adam \& Crispin Thurlow. 2010. Tourism Discourse. Language and Global Mobility. Palgrave Macmillan UK.

Johnstone, Barbara. 2018. Discourse Analysis. 3rd edn. Hoboken, NJ: John Wiley \& Sons.

Jørgensen, Marianne \& Louise Phillips. 2002. Discourse Analysis as Theory and Method. London, Thousand Oaks, New Delhi: SAGE Publications, Ltd.

Kalyango Jr., Yusuf \& Monika Kopytowska (eds.). 2014. Why discourse matters: Negotiating identity in the mediatized world. Peter Lang: New York.

Karasik, Vladimir. 2002. Yazykovoj krug: lichnost', koncepty, diskurs [Language circle: personality, concepts, discourse]. Volgograd: Peremena.

Kibrik, Andrei. A. 2009. Modus, zanr i parametry klassifikacii diskursov [Modus, genre and other parameters of discourse classification]. Voprosy Yazykoznanyja 2.3-21. [Electronic resource]. URL: http://iling-ran.ru/kibrik/Discourse_classification@VJa_2009.pdf (Accessed 01 March 2019).

Koshkarova, Natalya N. 2019. Linguistic, Pragmatic, and Stylistic Peculiarities of 2018 FIFA World Cup Representation in British Media-Discourse. Russian Journal of Linguistics 23 (3). 802-819. DOI: 10.22363/2312-9182-2019-23-3-802-819.

Langlotz, Andreas \& Miriam A. Locher. 2017. (Im)politeness and emotion. In Jonathan Culpeper, Michael Haugh \& Dániel Z. Kádár (eds.), Palgrave Handbook of Linguistic (Im)Politeness, 287-322. London: Palgrave. 
Larina, Tatiana V., Vladimir I. Ozyumenko \& Svetlana Kurteš. 2017. I-identity vs we-identity in language and discourse: Anglo-Slavonic perspectives. Lodz Papers in Pragmatics 13 (1). 195-215.

Larina, Tatiana, Vladimir Ozyumenko \& Douglas Mark Ponton. 2019. Persuasion strategies in media discourse about Russia: linguistic ambiguity and uncertainty. Lodz papers in Pragmatics 15 (1) 3-22. DOI: https://doi .org/10.1515/lpp-2019-0002.

Larina, Tatiana \& Douglas M. Ponton (forthcoming). Tact or frankness: Intercultural pragmatics in the blind peer review genre. Intercultural Pragmatics.

Leontovich, Olga A. 2019. New forms of urban discourse as a reflection of social change. Communication Studies (Russia) 6 (3). 645-654. DOI: 10.25513/2413-6182.2019. 6(3).645-654.

Locher, Miriam A. 2017. Reflective Writing in Medical Practice: A Linguistic Perspective. Bristol: MultilingualMatters.

Locher, Miriam A. \& Tatiana V. Larina. 2019. Introduction to politeness and impoliteness research in global contexts. Russian Journal of Linguistics 23 (4). 873-903. DOI: 10.22363/2312-91822019-23-4-873-903.

Macdonald, Myra. 2003. Exploring Media Discourse (Understanding Media Series). London: Arnold.

Mackenzie, J. Lachlan \& Laura Alba-Juez (eds.). 2019. Emotion in Discourse. Pragmatics and Beyond New Series 302. Amsterdam / Philadelphia: John Benjamins Publishing Company.

Matheson, Donald. 2005. Media Discourses: Analysing Media Texts. Open University Press.

Mills, Sara. 2003. Gender and politeness. Cambridge: Cambridge University Press.

Molodychenko, Evgeni. 2016. Cennosti i ocenka v diskurse konsyumerizma: lingvopragmaticheskij i kriticheskij analiz [Values and evaluation in discourse of consumerism: a pragmalinguistic analysis]. Filologiya. 122-130. DOI: 10.17238/issn2227-6564. 2016.3.122.

Molodychenko, Evgeni. 2020. Metasemiotic projects and lifestyle media: Formulating commodities as resources for identity enactment. Russian Journal of Linguistics 24 (1). 117-136. DOI: 10.22363/2687-0088-2020-24-1-117-136.

Montgomery, Martin. 2007. Discourse of Broadcast News: A Linguistic Approach. Routledge.

Naydenova, Natalia S. 2018. Modern linguistics through post-secular perspective. Russian Journal of Linguistics 22 (4). 988-1000. DOI: 10.22363/2312-9182-2018-22-4988-1000.

Nefedov, Sergei T. \& Valeria E. Chernyavskaya. 2020. Context in linguistics: pragmatic and discourse analytical dimension. Tomsk State University Journal of Philology 63. 83-97. DOI: 10.17223/19986645/63/5.

Nunan David. 1993. Introducing Discourse Analysis. London: Penguin English.

Olyanich, Andrey V. 2003. Gastronomicheskiy diskurs v sisteme massovoy kommunikatsii: semantiko-semioticheskiye kharakteristiki [Gastronomic discourse in the system of mass communication: semantic-semiotic specifications]. Massovaya kul'tura na rubezhe XX-XXI vekov: chelovek i ego diskurs, 167-201. Moscow.

Ozyumenko, Vladimir. 2017. Media discourse in an atmosphere of information warfare: From manipulation to aggression. Russian Journal of Linguistics 21(1). 203-220.

Ponton, Douglas. 2016. Movement and meaning: Towards an integrated approach to political discourse analysis. Russian Journal of Linguistics 20 (4). 122 - 139.

Ponton, Douglas \& Tatiana V. Larina. 2016. Discourse analysis in the 21st century: Theory and practice (I). Russian Journal of Linguistics 21 (1). 7-25.

Ponton, Douglas \& Tatiana V. Larina. 2017. Discourse analysis in the 21 st century: Theory and practice (II). Russian Journal of Linguistics 20 (4). 7-21. 
Talbot, Mary. 2007. Media Discourse: Representation and Interaction. Edinburgh University Press.

van Dijk, Teun A. (eds.). 1985. Discourse and Communication. New Approaches to the Analysis of Mass Media Discourse and Communication. Series: Research in Text Theory 10. De Gruyter. DOI: https://doi.org/10.1515/9783110852141.

van Dijk, Teun A. 1988. News as discourse. Hillsdale, NJ: Lawrence Erlbaum.

van Dijk, Teun A. 2006. Ideology and discourse analysis. Journal of Political Ideologies, Routledge, 11 (2). 115-140.

van Dijk, Teun A. 2009. Society and Discourse: How Social Contexts Influence Text and Talk. Cambridge University Press.

van Dijk, Teun A. (eds.). 2011. Discourse Studies: A Multidisciplinary introduction. SAGE.

Resta, Simonetta. 1998. Words and social change. The impact of power and ideology on the language of Economics and Law, Asp 19-22. [Electronic resource]. URL: http://journals.openedition.org/asp/2760. (Accessed 14 March 2020). DOI : https://doi.org/10.4000/asp. 2760

Saville-Troike, Muriel. 1994. Communicative Competence. In Ronald E. Asher (eds.), The Encyclopedia of Language and Linguistics 2. 538. Oxford, New York, Seoul, Tokyo: Pergamon Press.

Schiffrin, Deborah. 1995. Approaches to Discourse. Blackwell.

Shahovsky, Victor I. 2015. Golos emotsiy v yazykovom kruge homo sentiens [Voice of emotion in the linguistic circle of homo sentiens]. 3rd edn. Moscow: Knizhnyj dom «LIBROKOM» Publ.

Shakhovsky, Victor I. 2018. The Cognitive Matrix of Emotional-Communicative Personality. Russian Journal of Linguistics 22 (1). 54 -79. DOI: 10.22363/2312-9182-2018-22-1-54-79.

Sheigal, Elena. 2004. Semiotika politicheskogo diskursa [Political discourse semiotics]. Moscow: Gnozis.

Sériot, Patrick. 1999. Kak chitayut teksty vo Francii [How they read texts in France]. Kvadratura smysla. Frantsuskaya škola analiza diskursa, 12-53. M.: Progress.

Sériot, Patrick. 2012. Structure and the Whole. East, West and Non-Darwinian Biology in the Origins of Structural Linguistics / Translated from French by Amy Jacobs-Colas. Mouton De Gruyter.

Skålén, Per, Martin Fougère \& Markus Fellesson. 2008. Marketing Discourse: A Critical Perspective. London \& New York: Routledge.

Solopova, Olga \& Anatoly Chudinov. 2018. Diachronic Analysis of Political Metaphors in the British Corpus: from Victory Bells to Russia's V-Day. Russian Journal of Linguistics 22 (2). 313-337. DOI: 10.22363/2312-9182-2018-22-2-313-337.

Titscher, Stefan, Michael Meyer, Ruth Wodak \& Eva Vetter. 2000. Methods of Text and Discourse Analysis: In Search of Meaning. 1st edn. SAGE Publications Ltd.

Unger, Johann W. 2016. The interdiciplinarity of critical discourse studies research. Palgrave communications.

Watts, Richard. 2003. Politeness. Cambridge. Cambridge University press.

Williams, Glyn. 1999. French Discourse Analysis. The method of post-structuralism. London and New York: Routledge.

Yule, George. 1999. The Study of Language. 2nd edn. Cambridge University Press.

Бобырева Е.В. Религиозный дискурс: ценности, жанры, стратегии: (на материале православного вероучения). Волгоград: Перемена, 2007.

Дементьев В.В. Жанры речи и дискурс: место жанроведческих исследований в парадигме дискурс-анализа // Russian Journal of Linguistics. 2016. Т. 20. № 4. C. 103-121.

Добросклонская Т.Г. Массмедийный дискурс как объект научного описания // Научные ведомости. Серия Гуманитарные науки. 2014. № 13 (184). Вып. 22. С. 181-187. 
Дубровская Т.В. Метапрагматика осуществления правосудия в дискурсе российских и английских судей // Russian Journal of Linguistics. 2017. Т. 21. № 1. С. 73-90.

Иванова С.В. Актовая речь как гибридная полидискурсивная практика // Russian Journal of Linguistics. 2017. T. 21. № 1. C. 141-160.

Иванова С.В. Стилистика и риторика лайфстайл-дискурса // Дискурс профессиональной коммуникации. 2019. № 1 (2). С. 8-21.

Иссерс О.С. Дискурсивная практика как наблюдаемая реальность // Вестник Омского университета. 2011. № 4. С. 227-232.

Карасик В.И. Языковой круг: личность, концепты, дискурс. Волгоград, 2002.

Кибрик А.А. Модус, жанр и другие параметры классификации дискурсов. Вопросы языкознания. 2009. № 2. С. 3-21. [Электронный pecypc]. URL: http://iling-ran.ru/kibrik/ Discourse_classification@VJa_2009.pdf (дата обращения: 01.03.2020).

Кошкарова Н.․․ Лингвопрагматические и жанрово-стилистические особенности репрезентации чемпионата мира по футболу 2018 г. в британском медиадискурсе // Russian Journal of Linguistics. 2019. T. 23. № 3. C. 802-819. DOI: 10.22363/23129182-2019-23-3-802-819.

Леонтович О.А. Новые формы урбанистического дискурса и их социальные истоки // Коммуникативные исследования. 2019. Т. 6. № 3. С. 645-654. DOI: 10.25513/24136182.2019.6(3).645-654.

Молодыченко Е.Н. Ценности и оценка в дискурсе консюмеризма: лингво-прагматический и критический анализ // Филология. 2016. C. 122 - 130. DOI: 10.17238/issn22276564.2016.3.122.

Молодыченко Е.Н. Метасемиотические проекты и лайфстайл-медиа: дискурсивные механизмы превращения предметов потребления в ресурсы выражения идентичности // Russian Journal of Linguistics. 2020. T. 24. № 1. C. 117-136. DOI: 10.22363/26870088-2020-24-1-117-136.

Найденова Н.С. Современная лингвистика в постсекулярной перспективе // Russian Journal of Linguistics. 2018. T. 22. № 4. C. 988-1000. DOI: 10.22363/2312-9182-201822-4-988-1000.

Нефедов С.Т., Чернявская В.Е. Контекст в лингвистическом анализе: прагматическая и дискурсивно-аналитическая перспектива // Вестник Томского государственного университета. Филология. 2020. № 63. 83-97. DOI: 10.17223/19986645/63/5.

Олянич А.В. Гастрономический дискурс в системе массовой коммуникации: семантикосемиотические характеристики // Московская культура на рубеже XX-XXI веков: человек и его дискурс. М.: Институт языкознания РАН, 2003. С.167-201.

Озюменко В.И. Медийный дискурс в ситуации информационной войны: от манипуляции - к агрессии // Russian Journal of Linguistics. 2017. Т. 21. № 1. С. 203-220.

Серио П. Как читают тексты во Франции // Квадратура смысла: Французская школа анализа дискурса. М.: Прогресс, 1999. С.12-53.

Солопова О.А., Чудинов А.П. Диахронический анализ метафор в британском корпусе текстов: колокола победы и Russia's V-Day // Russian Journal of Linguistics. 2018. Т. 22. № 2. С. $313-337$.

Чернявская В.Е. Методологические возможности дискурсивного анализа в корпусной лингвистике // Вестник Томского государственного университета. Филология. 2017. 50. 135-148. DOI: 10.17223/19986645/50/9.

Чернявская В.Е. Дискурсивный анализ и корпусные методы: необходимое доказательное звено? Объяснительные возможности качественного и количественного подходов // Вопросы когнитивной лингвистики. 2018. № 2. С. 31-37. DOI: 10.20916/1812-32282018-2-31-37. 
Шаховский В.И. Голос эмоций в языковом круге homo sentiens. Изд. 3-е, стер. М.: Книжный дом «ЛИБРОКОМ», 2015.

Шаховский В.И. Когнитивная матрица эмоционально-коммуникативной личности // Russian Journal of Linguistics. 2018. T. 22. № 1. C. 54-79. DOI: 10.22363/2312-91822018-22-1-54-79.

Шейгал Е.И. Семиотика политического дискурса. М.: Гнозис, 2004.

\section{Bionotes:}

MAGDALÉNA BILÁ is Dr. of Philology, Full Professor at the Institute of British and American Studies, Faculty of Arts, The University of Prešov in Prešov. Her research interests include comparative and contrastive studies (juxtaposing English and Slovak), discourse analysis, and translation studies (conceptualization in a source and a target language).

\section{Contact information:}

Institute of British and American Studies, Faculty of Arts, University of Prešov, 17 Novembra Street 1, 08001 Prešov, Slovakia

e-mail:magdalena.bila@unipo.sk

SVETLANA V. IVANOVA is Dr. of Philology, Full Professor, Head of English Philology Department at Pushkin Leningrad State University. Research Interests: Media Linguistics, Cultural Linguistics, Discourse Analysis of Mass Media, Political Linguistics.

\section{Contact information:}

Pushkin Leningrad State University

10, Peterburgskoye shosse, Saint-Petersburg, 196605, Russia

e-mail: svet_victoria@mail.ru

ORCID ID: 0000-0002-0127-9934

Scopus Author ID: 57194882590

\section{Сведения об авторах:}

МАГДАЛЕНА БИЛА - доктор филологических наук, профессор Института британских и американских исследований гуманитарного факультета Прешовского университета в Прешове. Ее научные интересы включают сопоставительное языкознание (сопоставление английского и словацкого языков), анализ дискурса и переводоведение.

\section{Контактная информация:}

Institute of British and American Studies, Faculty of Arts, University of Prešov, 17 Novembra street 1, 08001 Prešov, Slovakia

E-mail: magdalena.bila@unipo.sk

СВЕТЛАНА ВИКТОРОВНА ИВАНОВА - докТор филологических наук, профессор, заведующий кафедрой английской филологии Ленинградского государственного университета им. А.С. Пушкина, член редколлегии журнала Russian Journal of Linguistics. Сфера научных интересов: медиалингвистика, лингвокультурология, дискурс-анализ текстов СМИ, политическая лингвистика, теория текста.

\section{Контактная информация:}

Ленинградский государственный университет имени А.С. Пушкина

196605, Россия, г. Санкт-Петербург, Пушкин, Петербургское шоссе, д. 10

e-mail: svet_victoria@mail.ru

ORCID ID: 0000-0002-0127-9934

Scopus Author ID: 57194882590 